\title{
Incidence of Salmonella in Imported Day-Old Ducklings. Brazil, 1998-2003
}

-Author(s)
SAM Ribeiro*
MCM Galleti
MA Orsi
AR Ferrati
AO Mendonça
L Doretto Júnior
SCA Camillo
D Reischak
Laboratório Nacional Agropecuário -
LANAGRO/SP
Ministério da Agricultura, Pecuária e
Abastecimento - MAPA

\section{Mail Address}

SAM Ribeiro

Laboratório Nacional Agropecuário - Lanagro/ $S P$

Rua Raul Ferrari, s/n

Jardim Santa Marcelina

13.094-430 - Campinas, SP, Brasil

Fone: 1932520155

Fax: 1932524835

E-mail: simone_ribeiro2002@yahoo.com.br

\section{Keywords}

Salmonella, imported ducklings, isolation.

\section{ABSTRACT}

The occurrence of Salmonella in a samples of 40 imported day-old duckling flocks was assessed from 1998 to 2003 according to the guidelines of the Brazilian National Poultry Health Program (Programa Nacional de Sanidade Avícola-PNSA). The pathogen was recovered from 26 flocks (65.0\%). The most common serovars were S. Saintpaul and S. Kottbus. Up to four serovars were isolated from a single flock. Transportation box swabs (82.6\%) and yolk sac pool (47.1\%) showed the highest and the lowest frequency of Salmonella isolation, respectively. The high percentage of Salmonella isolation from imported day-old ducklings causes concern because of the zoonotic potential of this agent and its economical importance to commercial poultry breeding.

\section{INTRODUCTION}

Salmonellae are enterobacteria distributed worldwide and grouped in 2,541 serovars $(C D C, 2004)$. Approximately 2,000 of them are potentially pathogenic to humans (OIE, 2000). It is estimated that 1.4 million people are affected by salmonellosis yearly in the United States, causing around 16,800 hospitalizations (1.2\%) and 600 deaths (Mead et al., 1999).

Considering the possible transmission routes of Salmonella to humans, it is worthy mentioning the direct contact with animals like reptiles and birds, which is especially important to infections in children (CDC, 2000), and the consumption of contaminated food, mainly poultry-derived foodstuffs (Dansk Zoonosecenter, 1998). In 2002, a total of 16,580 cases caused by foodborne agents were diagnosed in the United States. From these, Salmonella was the most common infectious agent $(6,028$ cases) (CDC, 2003).

Although ducks are very resistant to systemic infection caused by Salmonella, they are potential reservoirs of this organism and may shed it in the feces, contaminating the environment (Barrow et al., 1999). Outbreaks of human salmonellosis caused by contact with ducks have been reported in some countries, such as Australia, United States, United Kingdom and Denmark (Merritt \& Herlihy, 2003; CDC, 2000; Public Health Laboratory Service, 2000; Dansk Zoonosecenter, 1998). Moreover, the consumption of contaminated duck eggs has been reported as the cause of salmonellosis outbreaks in Italy, Thailand and United States (Nastasi et al., 1998; Saitanu et al., 1994; Baker et al., 1985).

In Brazil, the role of ducks as a source of Salmonella infection is unknown and the literature about this issue is scarce. According to a report from the Laboratório de Enterobactérias of the Departamento de Bacteriologia (Instituto Oswaldo Cruz - FIOCRUZ), Salmonella has been isolated from 143 samples $(6,7 \%)$ of the all collected by ducks, from 1962 to 1991 (Hofer et al., 1997). 
In spite of the few data about duck production and commercialization, and the consumption of duck meat and by-products in Brazil, more than 70,000 day-old ducklings were imported between 1998 and 2003 (LANAGRO/SP, unpublished results).

Imported animals represent a risk of introducing infectious agents in the country, including different serovars of Salmonella (Ribeiro et al., 2003). Therefore, the National Poultry Health Program (Programa Nacional de Sanidade Avícola-PNSA) requires that all imported birds and egg batches should be analyzed for infectious agents, including Salmonella (Brasil, 1999).

The aim of the present study was to report the occurrence of Salmonella in day-old ducklings imported by Brazilian companies from 1998 to 2003.

\section{MATERIALS AND METHODS}

Samplings were performed following current governmental guidelines (Brasil, 1999). All samples were collected in airports by inspectors from MAPA. Twenty day-old ducklings were collected per flock. Dead ducklings, when present, were also sampled. In such cases, a maximum of 20 dead birds per flock were used. Swabs were individually taken from transportation boxes of each imported flock (maximum 30 boxes per flock). After sampling, swabs were placed into $1 \%$ buffered peptone water for transportation and taken to the laboratory (Laboratório Nacional Agropecuário-LANAGRO/SP - MAPA). The samples were analyzed according to the National Poultry Health Program (PNSA) guidelines for imported birds (Portaria 126, November 3rd, 1995 - MAPA).

Ducklings were killed by decapitation and necropsied, and pools of internal organs (liver, spleen and gall bladder), of yolk sac and caecum were collected from each flock. From ducklings that were dead at the time of sampling, only a pool of internal organs was collected. Pools of internal organs, yolk sac, caecum and swab of transportation box were enriched in both tetrathionate and Rappaport-Vassiliadis enrichment broths for 24 hours at two different temperatures $\left(37^{\circ} \mathrm{C}\right.$ and $\left.42^{\circ} \mathrm{C}\right)$. Afterwards, an aliquot of each broth was transferred to three semi-solid media: MacConkey agar, Hektoen agar and Brilliant-green Phenol-red Lactose Sucrose agar with Novobiocin, which were incubated at $37^{\circ} \mathrm{C}$ for 24 hours. Isolation of suspected colonies was performed in Rambach agar at $37^{\circ} \mathrm{C}$ for 24 hours. Suspected colonies were confirmed as Salmonella genus by biochemical tests.
Salmonella isolates were serotyped as $S$. Enteritidis, S. Pullorum, S. Typhimurium, S. Gallinarum or S. sp. by slide agglutination test. These four serovars were herein considered because they are included in the Brazilian National Poultry Health Program (PNSA). Serotyping was performed or the results were confirmed (in case of the four above mentioned serovars) at a reference laboratory (Laboratório de Enterobactérias - Departamento de Bacteriologia Instituto Oswaldo Cruz -FIOCRUZ).

\section{RESULTS}

From 1998 to 2003, three different companies imported 40 flocks of day-old ducklings from the same country. Among them, 26 (65.0\%) flocks were positive for Salmonella (Table 1).

Salmonella Saintpaul (29.8\%) and S. Kottbus $(26.3 \%)$ were the most frequently isolated serovars. The highest number of different Salmonella serovars obtained from a single flock was four. The most common association of serovars was $S$. Saintpaul and $S$. Kottbus (Table 2, Figures 1 and 2). The samples with the highest and the lowest frequencies of Salmonella in positive flocks were swabs taken from transportation boxes $(82.6 \%)$ and yolk sac pools $(47.1 \%)$, respectively (Table 3 and Figure 3).

\begin{tabular}{|c|c|c|}
\hline Year & Imported flocks (n) & Number of positive flocks (\%) \\
\hline 1998 & 04 & $04(100 \%)$ \\
\hline 1999 & 06 & $01(16.7 \%)$ \\
\hline 2000 & 02 & $01(50.0)$ \\
\hline 2001 & 07 & $04(57.1)$ \\
\hline 2002 & 09 & $06(66.7)$ \\
\hline 2003 & 12 & $10(83.3)$ \\
\hline TOTAL & 40 & $26(65.0)$ \\
\hline
\end{tabular}

\section{DISCUSSION}

The high frequency of Salmonella recovery from imported day-old ducklings causes great concern because of the zoonotic potential of this pathogen and its economical importance to commercial poultry breeding. Macroscopic lesions were not observed in the dead or sacrificed birds, which may be associated with the inability of some serovars to multiply in the duck reticulo-endothelial system (Barrow et al., 1999). However, the isolation of Salmonella from different organs suggests that ducks may harbour Salmonella in their viscera and shed it in the faeces. 
SAM Ribeiro, MCM Galleti, MA Orsi, AR Ferrati, AO Mendonça, L Doretto Júnior, SCA Camillo, D Reischak

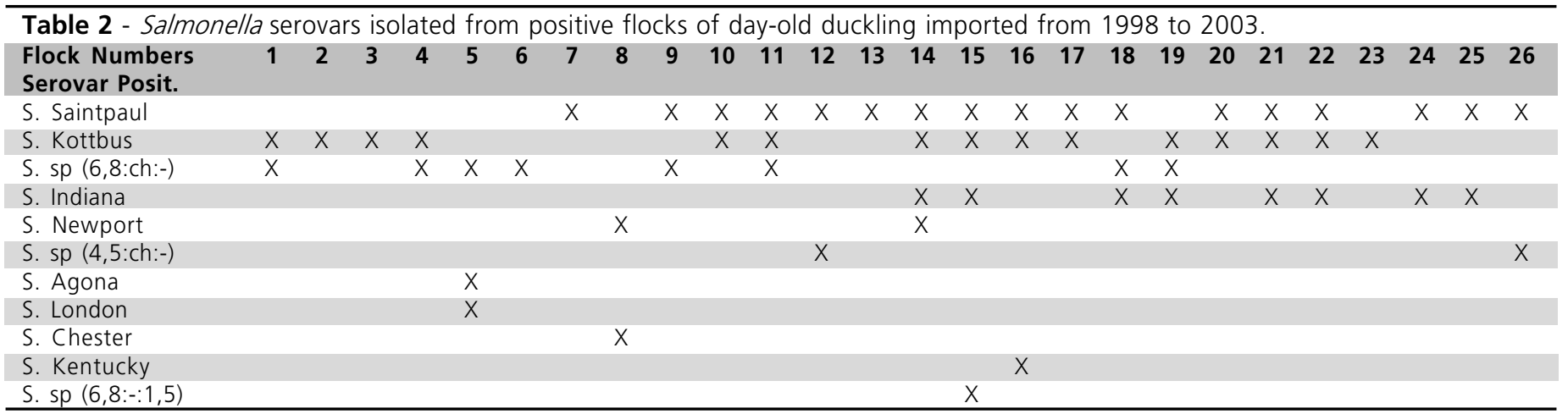

\begin{tabular}{|c|c|c|c|c|c|}
\hline Flock & Liver pool (Live birds) & Yolk sac pool & Caecum pool & Transportation box swab & Liver pool (Dead birds) \\
\hline 1 & ND & ND & ND & - & + \\
\hline 2 & ND & ND & ND & + & + \\
\hline 3 & + & + & WI & WI & ND \\
\hline 4 & - & ND & - & + & ND \\
\hline 5 & + & ND & - & - & ND \\
\hline 6 & + & + & + & + & ND \\
\hline 7 & - & ND & + & - & - \\
\hline 8 & WI & WI & WI & WI & WI \\
\hline 9 & - & - & + & + & ND \\
\hline 10 & ND & ND & ND & + & - \\
\hline 11 & - & - & - & + & ND \\
\hline 12 & WI & WI & WI & WI & WI \\
\hline 13 & + & + & + & + & + \\
\hline 14 & + & + & + & + & ND \\
\hline 15 & + & + & + & + & + \\
\hline 16 & + & + & + & + & ND \\
\hline 17 & + & - & + & + & ND \\
\hline 18 & + & - & + & - & ND \\
\hline 19 & + & - & + & + & + \\
\hline 20 & + & ND & + & + & + \\
\hline 21 & + & + & + & + & ND \\
\hline 22 & + & - & + & + & + \\
\hline 23 & - & - & - & + & - \\
\hline 24 & + & + & + & + & ND \\
\hline 25 & + & - & + & + & + \\
\hline 26 & + & - & - & + & + \\
\hline
\end{tabular}

ND = Not done; $W I=$ Without information; $(+)=$ Positive flocks; $(-)=$ Negative flocks

Ducks are probably asymptomatic reservoirs of Salmonella and, consequently, may act as infection sources to other species, including humans. The isolation of Salmonella Indiana in frozen duck meat for human consumption (Food Microbiology Departament, LANAGRO/SP-MAPA, unpublished results) corroborates this hypothesis.

The low frequency of Salmonella in yolk sacs occurred because this is a vestigial organ in ducks and it is quickly absorbed in the first days after birth. In most cases, the sampling of this organ was not possible (see Table 3 ). Nevertheless, the high percentage of isolation from liver, caecum and swabs from transportation boxes $(75.0 \%$ to $82.6 \%)$, suggest that these are the most appropriate specimens for Salmonella recovery.
Brazilian official guidelines recommend that breeder farms should be free of $S$. Gallinarum, $S$. Pullorum, $S$. Enteritidis and $S$. Typhimurium, but other serovars are not considered (Brasil, 2003). However, it is known that some serovars like $S$. Indiana, $S$. Newport and $S$. Saintpaul have caused outbreaks of salmonellosis in human (Public Health Laboratory Service, 1996; CDC, 2002; Hata et al., 2003). It is suggested that the current guidelines should be reviewed in order to include other serovars, especially those of public health importance.

In the present study, more than one Salmonella serovar were recovered from most of the positive flocks and four serovars were cultured from a single flock (Figure 2). These results indicate that ducklings may eliminate different serovars concomitantly, 
SAM Ribeiro, MCM Galleti, MA Orsi, AR Ferrati, AO Mendonça, L Doretto Júnior, SCA Camillo, D Reischak
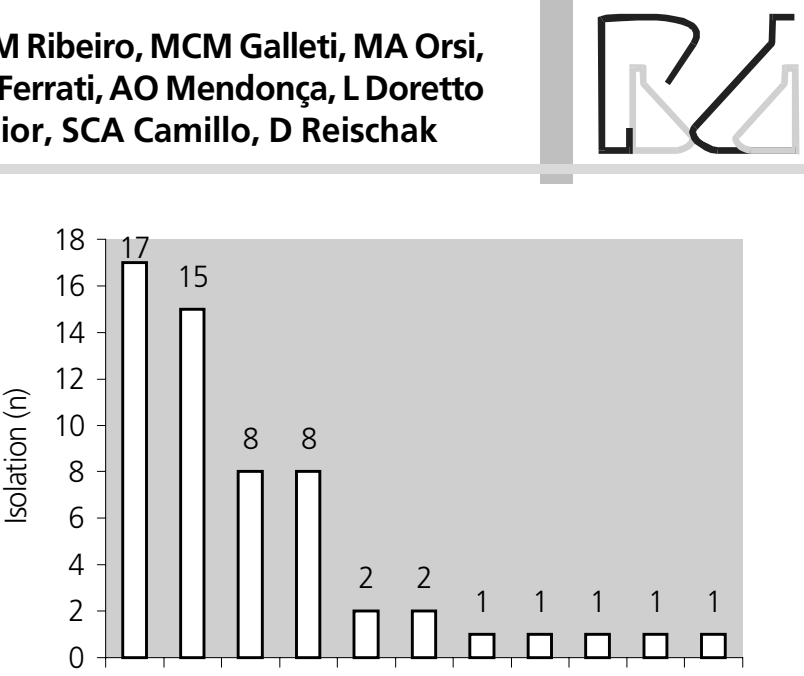

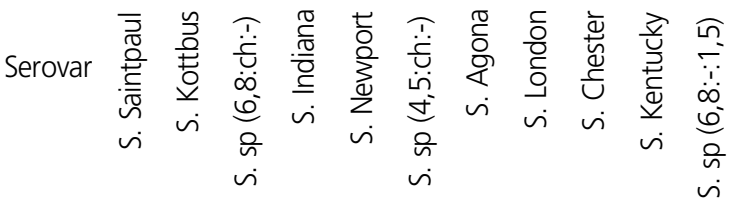

Figure 1 - Salmonella serovars isolated from imported day-old ducklings from 1998 to 2003.

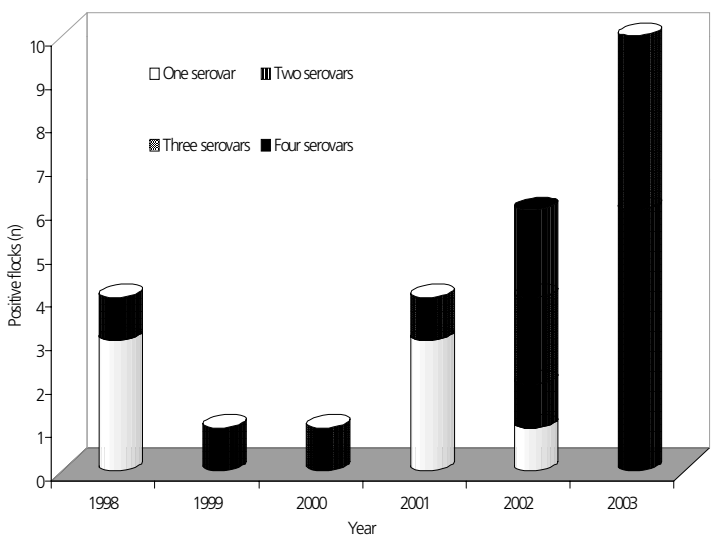

Figure 2 - Number of different Salmonella serovars isolated from a single flock of imported day-old ducklings.

showing the importance of this species for Salmonella spreading.

Further studies on salmonellosis pathogeny in ducks and epidemiological surveillance data from commercial duck breeding are fundamental to clarify the importance of this species on the epidemiology of Salmonella and to establish more severe procedures to control this important zoonosis.

\section{REFERENCES}

Baker RC, Qureshi RA, Sandhu TS, Timoney JF. The frequency of salmonellae on duck eggs. Poultry Science 1985; 64(4):646-52

Barrow PA, Lovell MA, Murphy CK, Page K. Salmonella infection in a commercial line of ducks; experimental studies on virulence, intestinal colonization and immune protection. Eidemiology and
Incidence of Salmonella in Imported Day-Old Ducklings. Brazil, 1998-2003

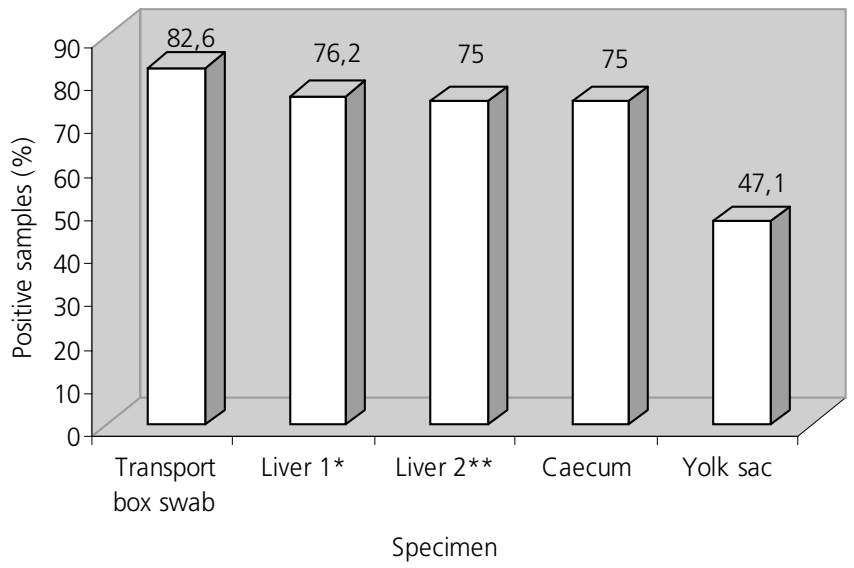

Figure 3 - Percentage of positive samples for Salmonella isolation, according to the material analyzed, among imported day-old ducklings flocks positives to Salmonella isolation.

Infection 1999; 123(1):121-32.

BRASIL. Programa Nacional de Sanidade Avícola. Atos legais. Instrução Normativa $n^{\circ} 14$. Diário Oficial da Republica Federativa do Brasil, Poder executivo, Brasília - DF, 29 jun 1999. Seção 1.

BRASIL. Programa Nacional de Sanidade Avícola. Atos legais. Instrução Normativa $n^{\circ} 78$. Diário Oficial da Republica Federativa do Brasil, Poder executivo, Brasília - DF, 03 nov 2003. Seção 1.

BRASIL. Programa Nacional de Sanidade Avícola. Atos legais. Portaria $n^{\circ}$ 126. Diário Oficial da Republica Federativa do Brasil, Poder executivo, Brasília - DF, 03 nov 1995. Seção 1.

CDC. Salmonellosis associated with chicks and ducklings. Morbidity and Mortality Weekly Report 2000; 49(14):297-9.

CDC. Outbreak of multidrug-resistant Salmonella Newport. Morbidity and Mortality Weekly Report 2002; 51(25):545-8.

CDC. Preliminary FoodNet data on the incidence of foodborne illnesses - selected sites. Morbidity and Mortality Weekly Report 2003; 52(15):340-3.

CDC. Salmonella surveillance: Annual Summary, 2003. Available at: http://www.cdc.gov/ncidod/dbmd/phlisdata/salmonella.htm. Accessed on May 13th, 2003.

Dansk Zoonosecenter. Salmonella. In: Annual Report on Zoonosis in Denmark 1998. cap. 1.

Hata M, Suzuki M, Matsumoto M, Takahashi M, Yamasaki M, Hiramatsu R, Matsui H, Sakae K, Suzuki Y, Miyazaki Y. A new clonal line of Salmonella Saintpaul having emerged and prevailed since 1999 in Aichi, Japan. Japanese Journal of Infectious Diseases 2003; $56: 77-9$

Hofer E, Silva Filho SJ, Reis EMF. Prevalência de sorovares de Salmonella isolados de aves no Brasil. Pesquisa Veterinária Brasileira 1997; 17(2):55-62. 
Mead PS, Slutsker L, Dietz V, Mccaig LF, Bresee JS, Shapiro C, Griffin PM, Tauxe RV. Food-related illness and death in the United States. Emerging Infectious Diseases 1999; 5(5):607-25.

Merritt TD, Herlihy C. Salmonella outbreak associated with chicks and ducklings at childcare centres. The Medical Journal of Australia 2003; 179(10):63-4.

Nastasi A, Mammina C, Piersante GP, Robertazzo M, Caruso P. A foodborne outbreak of Salmonella enteritidis vehicled by duck and hen eggs in southern Italy. New Microbiology 1998; 21(1):93-6.

OIE. Salmonellosis. In: Manual of standards for diagnostic tests and vaccines 2000. OIE, 2000. Cap. X. 4.

Public Health Laboratory Service. Salmonella indiana. Communicable Disease Report CDR Weekly 1996; 6(16):135.

Public Health Laboratory Service. Outbreak of salmonellosis associated with chicks and ducklings at a children's nursery. Communicable Disease Report CDR Supplement 2000; 10:14952.

Ribeiro SAM, Orsi MA, Doretto Jr L, Ferrati AR, Mendonça AO, Albieri SC, Yochida LT, Reischak D, Reis EMF. Isolamento de salmonelas de avestruzes importadas no período de nov/99 a set/ 02. In: Conferência Apinco 2003 de Ciência e Tecnologia Avícolas; 2003; Campinas, SP. Brasil: FACTA; 2003.

Saitanu K, Jerngklinchan J, Koowatananukul C. Incidence of salmonellae in duck eggs in Thailand. Southeast Asian Journal of Tropical Medicine \& Public Health 1994; 25(2):328-31. 


\section{FACTA}

\section{PUBLICAÇÕES FACTA}

Anais da Conferência APINCO'94

Anais da Conferência APINCO'95

Anais da Conferência APINCO'97

Anais da Conferência APINCO'98

Anais da Conferência APINCO'99 (2 vol)

Anais da Conferência APINCO'00 (2 vol)

Anais da Conferência APINCO'02 (1 vol)

Anais da Conferência APINCO'03 (1 vol)

Anais da Conferência APINCO'05 (2 vol)

II Simpósio Internacional de Coccidiose Aviária

Col. FACTA - Manejo de Frangos

II Simpósio da Doença de Gumboro

Simpósio FACTA de Postura Comercial

Doença das Aves

Fisiologia Aviária

Manejo da Incubação

Produção de Frangos de Corte

Manejo de Matrizes de Corte

Para maiores informações:

facta@facta.org.br ou Fone: (19) 3243-6555 